\title{
Contribution of waste bank in reducing greenhouse gas emissions in Bandung Regency
}

\author{
Idea Wening Nurani ${ }^{1}{ }^{*}$, Sandy Budi Wibowo ${ }^{2}$, Zithny Ilman Prihastopo ${ }^{1}$, Aura Puteri Pelangi ${ }^{1}$, and Sunardi Sunardi ${ }^{3}$ \\ ${ }^{1}$ Department of Development Geography, Faculty of Geography, Universitas Gadjah Mada, Indonesia \\ ${ }^{2}$ Department of Geographic Information Science, Faculty of Geography, Universitas Gadjah Mada, Indonesia \\ ${ }^{3}$ Department of Biology, Faculty of Mathematics and Natural Sciences, Universitas Padjadjaran, Indonesia
}

\begin{abstract}
Households with all their activities produce waste which can be a source of GHG emissions if not managed properly. Reducing waste from its source is one of the ways to reduce GHG emissions. In Bandung Regency, one of the ways to reduce household waste is by running the Waste Bank program. Research is needed to find out how much the reduction of GHG emissions from waste management in the Waste Bank. This study used a combination of quantitative and qualitative methods with descriptive analysis including IPCC method to estimate GHG emission reductions from waste management and in-depth interview with the operators in one of the Master Waste Banks (Bank Sampah Induk) in Bandung Regency, Y Waste Bank. The results showed that the potential GHG emission reductions from Y Waste Bank reached $0.016 \mathrm{Gg} \mathrm{CH}_{4}$ or equivalent to 401.273 tons of $\mathrm{CO}_{2}$ eq, reducing $\mathrm{GHG}$ emissions from total household waste in Bandung Regency by $0.0007 \%$. Program and technology innovations and also assistance for customers or fostered groups are expected to be able to increase the quantity of waste managed at the Y Waste Bank up to the household level so that it can give higher contribution in reducing GHG emissions in Bandung Regency.
\end{abstract}

\section{Introduction}

Climate change expert's consensus believe that the global warming is a natural phenomenon that accelerated by human activities, especially after the industrial revolution occurred [1-3]. One of the main causes of the earth's average temperature increase or scientifically known as global warming is caused by greenhouse gases (GHGs) $[4,5]$. The waste management is one of human activities that potentially emits the most significant greenhouse gasses (GHGs) such as Carbon Dioxide $\left(\mathrm{CO}_{2}\right)$ and Methane $\left(\mathrm{CH}_{4}\right)$ during its process.

The increasing trend of population [6-9], especially at household scale has implications for the increase in generated waste. The responsibility for waste management begins from the community at the household level and then elevate to a vertically higher structure to local's government responsibility. Reducing household waste from its source is a practical strategy to cope with solid waste problems. This strategy has been carried out in Bandung Regency, especially to support the campaign of Bandung Regency waste-free by 2020 . One of the pivot programs of this strategy is the Waste Bank, which focused on reducing household inorganics waste [10].

Activities undertaken at the waste bank include sorting and processing waste through Reduce, Reuse, Recycle scheme. Waste bank also undertakes selection of the type, condition and minimum weight of the waste. Through these stages, the impact of waste bank in reducing greenhouse gas emissions reduction can be understood [11].
Waste banks in Bandung Regency are focused on inorganic waste management. Recently, the Bandung Regency Government is running a program called one village one waste bank. Although they do not manage the organic waste by composting, which is considered as the best way to avoid methane production, the advance sorting and processing inorganic waste at waste banks are estimated to be able to reduce the amount of greenhouse gas emissions quite significant. It could reduce the waste collected in open dumping disposal site. Unmanaged waste mound has the potential to release GHG emissions into atmosphere from biological processes that happened [12]. This idea is in line with the Indonesian National Action Plan for Greenhouse Gas Emissions (RAN-GRK) document [13] which states that the focus of GHG emission reduction targets for waste management in low emission development schemes are solid waste, domestic water and accumulative waste from open dumping disposal site. These site produces significant amounts of methane and carbon dioxide emissions. Therefore, it is necessary to estimate GHG emission reductions from waste management through waste banks as one of the alternative recommendations for the Bandung Regency Government to implement sustainable waste management and facing the era of low-emissions development. In general, this study aims to provide recommendations on reducing greenhouse gas emissions from waste bank management. The specific objectives of this study are to: (1) calculate GHG emissions from household waste management without a waste bank; (2) calculate GHG

* Corresponding author : idea.nurani@ugm.ac.id 
emission reductions from household waste management in $\mathrm{Y}$ waste bank.

\section{Research methods}

The research method used was a combination of quantitative and qualitative methods. For answering research question number 1 , emission calculation was performed using the GHG emission calculation method from the 2006 Intergovernmental Panel on Climate Change (IPCC) for households' waste in Bandung Regency. Secondary data were obtained from Central Bureau of Statistics (Badan Pusat Statistik/BPS) and Environmental Agency of Bandung Regency (Dinas Lingkungan Hidup Kabupaten Bandung). A descriptive analysis was conducted. For answering research question number 2, data were collected by conducting in-depth interview with the operators of the Y Waste Bank as the informants as well as secondary data collection in the form of data record of the type and weight of waste processed there to calculate the emission of GHG. Purposive sampling was used to define the informants, director and manager of the waste bank. Interviews were recorded and transcribed. Analysis consist of transcribing, coding, clustering, labelling and interpreting the data. Analysis was focused on efforts from the waste bank operators to improve their waste management that contributes to GHG emission reduction. Triangulation of data was applied in this research where interview with key informants was combined with observation and literature/document analysis to make sure the data are valid [14].

This research took place at the Y Waste Bank located in Baleendah District, Bandung Regency. Y Waste Bank was originally established independently as waste bank unit by the local community since 2014 . This waste bank has been continued to grow since then and pointed as Master Waste Bank (Bank Sampah Induk) by the Bandung Regency Environmental Agency in 2016. The reason for choosing Y Waste Bank as research location is due to the fact that this particular waste bank is one of the earliest and progressive waste banks that still operated until the research took place.

\section{Results}

\subsection{Estimated GHG emissions from household waste management without a waste bank}

Based on the results of the GHG emissions calculation for household waste in Bandung Regency in 2017, the amount of GHG emissions produced reached $23.88 \mathrm{Gg}$ $\mathrm{CH}_{4}$ / year or equivalent to $597029 \mathrm{t} \mathrm{CO}_{2}$ eq. This value is obtained with the assumption that all waste is piled up at the Sarimukti open dumping waste disposal and takes into account the number of people population in Bandung Regency as main source of waste generation. This open dumping system where garbage is left in the open air and mounded up is still running at the Sarimukti, one of the waste disposals sites in Bandung Regency. According to
GHG emission calculation method from IPCC, the emission value result is greatly influenced by the type of waste management which has been carried out because it will affect the value of the methane correction emission factor used in the calculation [15].

Baleendah District produces the largest emissions with a value of $2.92 \mathrm{Gg} \mathrm{CH}_{4}$ or equivalent to $41516 \mathrm{t}$ of $\mathrm{CO}_{2}$ eq whilst Cilengkrang District produces the lowest emissions. This calculation is directly proportional to the largest and smallest population or households in the two districts, so that it affects the amount of waste generated proportionally.

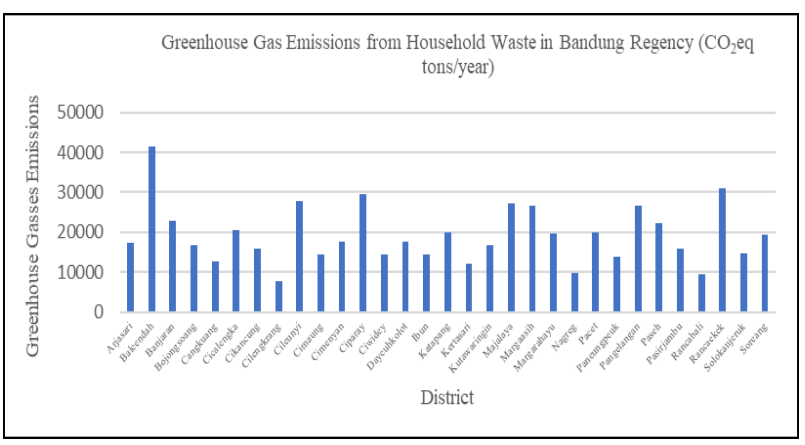

Fig.1. Greenhouse gas emissions from household waste in Bandung Regency 2017 (Source: Data Processing, 2019)

\subsection{Estimated GHG emissions from household waste management in a waste bank}

\subsubsection{Inorganic Waste Management Emissions}

During the one-year period (2017), Y Waste Bank received $169365 \mathrm{~kg}$ of waste with an average input of 14 $114 \mathrm{~kg}$ / month. From this value, GHG emissions that can be reduced based on IPCC calculations are approximately $0.00786 \mathrm{Gg} \mathrm{CH}_{4}$ or equivalent to $196.5 \mathrm{t} \mathrm{CO}_{2}$ eq. The most waste type that is received by the Y Waste Bank is plastic $(40 \%)$ and followed by paper $(37 \%)$. The rest of waste type including metal, glass and others.

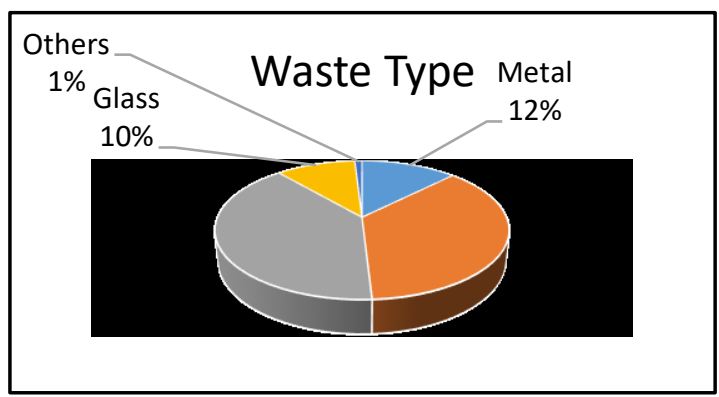

Fig. 2. Waste Type Managed by Y Waste Bank (Source: Y Waste Bank, 2019)

The informant stated that the amount of waste managed at the beginning showed a progressive pattern yet experience stagnation trends in recent years. Presence of junk business influences the customers' decision. Customers prefer to sell their waste to the junk buyers (tukang rongsokan) since they offer the higher price. 
"Previously, it had gone up, even 25 tons/month. But people tend to sell their waste to those who offer higher prices. One hundred rupiahs difference matters. Junk business always comes to the place where the waste bank operates. "(Informant 1)

Besides the presence of the competitor such as junk business, lack of human resources becomes the problem. It is also considered to be one of the obstacles that influences the quantity of the waste and customers.

"Lack of human resources. In the past, there were 200 fostered groups, now it is sagging, because we do not have enough energy to accompany them whenever they face problems." (Informant 2)

\subsubsection{Organic waste management emissions}

Y Waste Bank focuses on receiving inorganic waste from the local community. However, through composting training programs conducted in fostered groups, the potential for indirect organic waste reduction via waste banks is also worth to be considered. Nowadays, the customers of Y Waste Bank both individuals and groups, are distributed in 13 out of 31 districts in Bandung Regency. Based on information from the informant, groups could consist of neighborhoods or local community organizations (minimum of 20 families, institutions (minimum 40 people) or markets / merchants (minimum of 5 merchants). Based on Bandung Regency Environmental Agency data (2018), the composition of organic and inorganic waste in Bandung Regency is $51.04 \%$ to $48.96 \%$ ratio. With these assumptions, the potential for GHG emissions reduction from composting training organized by the Y Waste Bank reaches 0.0082 $\mathrm{Gg} \mathrm{CH}_{4}$ or equivalent to $204.8 \mathrm{t}$ of $\mathrm{CO}_{2} \mathrm{eq}$ from an estimated $176560 \mathrm{~kg}$ of organic waste [1].

1. "Inorganic for now. We have not managed organic waste but we have educated the customers to make compost." (Informant 1).

2. "We socialize the use of inorganic waste through waste banks and organic waste with bio pores. We facilitate training for that too." (Informant 2)

\subsubsection{Total emissions}

Based on the earlier calculation of organic and inorganic waste emissions, the total GHG emissions that can be reduced through waste management in the Y Waste Bank reaches $0.016 \mathrm{Gg} \mathrm{CH}_{4}$, equivalent to $401273 \mathrm{t} \mathrm{CO}_{2}$ eq. When compared with the total GHG emissions from households in Bandung Regency, this result is equal to $0.0007 \%$.

Based on the interview with the operators of the $\mathrm{Y}$ Waste Bank, creating customer awareness to manage waste independently is the main objective of the waste bank operation.
1 "Our goal is changing people's behavior. Business is not our main goal." (Informant 1)

2. "From the business perspective, running waste bank is really difficult. But from environment perspective, it is easy to educate people through innovation." (Informant 2)

Based on the interview with the operators, it is known that there are many programs created in waste bank. At present, the activities of the waste banks are not only limited in collecting waste from the community but are also able to carry out various collaborations with various institutions. Innovation activities happened to boost the development of Y Waste Bank. Current schemes include waste savings with Conventional Bank such as Bank Negara Indonesia (BNI), partnership with Convenience Store such as Alfamart, free medical treatment by collecting waste, sales of affordable staple food for fostered groups, training for fostered groups (one of them is in collaboration with the Bandung Phil Orchestra), practical programmer training (cooperation in the form of CSR with company) and provides training related to waste management both for the target group and at the request of outside parties. Networking plays important role in waste bank management.

"There are several important things that influence our waste bank. Number one is CSR (Corporate Social Responsibility); number two is fostered group assistance; number three is price we offer to customers since we already have the fixed buyers such as recycling industries" (Informant 2)

\section{Discussions}

The potential reduction of GHG emissions from waste management in the $\mathrm{Y}$ Waste Bank is approximately $0.0007 \%$ of the total GHG emissions produced from household waste in Bandung Regency. This percentage is indeed very small and looked insignificant. However, this value has abundant room of development depending on the role of the Waste Bank in the community. With its status as a Master Waste Bank (Bank Sampah Induk), Y Waste Bank has the opportunity to contribute greatly in the near future to deal with GHG emissions reduction, especially from household waste through its customer network and its sphere of influence.

The potential for GHG emission reductions through the waste bank is very much dependent on the amount of waste received. The greater the amount of waste collected, the greater the GHG emissions that can be reduced [16]. This is significantly influenced by the management of the Waste Bank in carrying out the activity of collecting, sorting and the further process of the waste processing. The ability of the waste bank operator to both encourage and attract customers to deposit their waste is essentially important.

The status of the Y Waste Bank as a Master Waste Bank increases the opportunity of the waste bank to manage abundant amounts of waste. This can be seen from the waste bank membership that not only accepts 
individual customers but also in the form of foster group units. This flexible and various types of membership increase the likelihood of the amount of waste collected due to the vast variations in socioeconomic levels of customers [17].

The amount of waste managed indeed will reflect the potential reduction in GHG emissions. However, the amount of waste managed by the waste bank is not the only benchmark for the waste bank in managing waste. There is something even more important compared to the amount of waste that has been managed, for instance the education for the customers so that they could manage their waste independently, with or without waste bank mechanism.

Based on the interview with the operators of the $\mathrm{Y}$ Waste Bank, creating customer awareness to manage waste independently is the main objective of the waste bank operation. The informant stated that the amount of waste managed at the beginning showed a progressive pattern yet experience stagnation trends in recent years. It is assumed that waste bank customers are getting smarter in managing their waste independently, so they no longer need to collect it through the waste bank. Surely, this hypothesis requires further research to be proven true.

Based on the interview with the operators of the waste bank, the key to the success of the Y Waste Bank is the sustainability value that underlies the waste bank operation. Y Waste Bank is not solely oriented to waste collection for environmental sustainability, but also maintain and secure both social and economic sustainability. There are social and economic benefits received by both operators and customers through waste bank operation [18]. The first key is to have the firm buyers so that they can offer attractive prices to the customers. It is a guarantee that all waste received by waste bank will be sold immediately after processed. The presence of wholesaler and factories as the main buyers of waste gives certainty to the economic value of the waste that has been collected. The second key is an innovative program that benefits customers. It is important to make sure that waste bank customers are not only economically viable but also socially empowered. The third key is a network of cooperation among waste bank with outside parties such as companies that have Corporate Social Responsibility (CSR) programs. Product diversification and affiliate expansion could improve the performance of a waste bank accordingly [19].

Waste bank legal status as a Foundation, as mandated at the Regulation of the Minister of Environment No. 13 of 2012 about Guidelines for the Implementation of Reduce, Reuse and Recycle through the Waste Bank also encourages the activities of the Waste Bank to become more independent $[20,21]$. Innovation activities can be realized by collaboration with other parties. Good networking increases the collaboration chances. The existence of CSR from the company is also injecting funds for the realization of the innovations. The support from the Bandung Regency government also facilitates the waste bank management to introduce and socialize the program to the new area so that the service area of the waste bank can be expanded. It is expected that the sphere of influence of Y Waste Bank could escalate from initially only one district to nowadays up to 13 districts in Bandung Regency. Government's support and commitment are utterly needed in handling waste, no exception to waste bank [22].

The greater the scope of service areas and the number of programs run by the $\mathrm{Y}$ Waste Bank becomes a challenge in the operations of the waste bank. Based on the interview with the operators, the process of assisting fostered groups is one of the main obstacles in the midst of limited human resources. Support and participation from members or customers are needed in the operation of the waste bank [23]. The use of information and communication technology can improve the waste management system in waste bank [24].

Unlike the neighborhood or villages scale waste banks which are generally individual members, members in the form of groups require special attention and guidance. It takes time and qualified human resources to be able to maintain the established membership. In the end, the task of managing the waste bank is no longer focused solely on the processing of waste in the waste bank but also emphasize on how to strengthen the foster groups to be able to empower socially and economically in managing their waste independently. Thus, efforts to reduce GHG emissions from waste management with the concept of reduce, reuse and recycle can be done earlier starting from the micro scale, which is household waste management.

\section{Conclusion}

The amount of GHG emissions from household waste in Bandung Regency is estimated to reach $23.88\left(\mathrm{Gg} \mathrm{CH}_{4} /\right.$ year) or equivalent to 597029 ( $\mathrm{CO}_{2} \mathrm{eq}$ ). The potential reduction in $\mathrm{GHG}$ emissions from waste management in the Waste Bank is approximately $0.016 \mathrm{Gg} \mathrm{CH}_{4}$ or equivalent to 401.273 tons of $\mathrm{CO}_{2}$ eq. This value reduces $0.0007 \%$ of the total GHG emissions from household waste in Bandung Regency. Program innovations and mentoring for customers or fostered groups are needed to increase the quantity of waste managed at the Waste Bank up to the household level so that it can contribute more to GHG emission reduction efforts in Bandung Regency. Further research is needed to explore the waste management in waste bank from customer's perspective to give the comprehensive understanding about contribution of waste bank in reducing GHG emission.

The authors acknowledge support from the Faculty of Geography, Universitas Gadjah Mada for the research funding and management of Y Waste Bank for the cooperation.

\section{References}

1. D. Waugh, Geography an Integrated Approach. Oxford: Oxford University Press (2009)

2. I. Ruiz, S.H. Faria, M.B. Neumann. Env. Sci. \& Pol. 108, 112-120 (2020)

3. S.B. Wibowo, Utilisation des classifications d'Oldeman et de Schmidt-Ferguson pour l'aptitude culturale des sols à Batu, Indonésie, In Hydrocomplexity: new tools for solving wicked 
water problems, IAHS, 1 July 2010, Paris, France. 2010.

4. C. Magazzino, M. Mele, N. Schneider. Wast. Man. 113, 508-520 (2020)

5. S. Akdag, H. Yıldırım. Heliyon. 6, 3: e03396. (2020)

6. J. Chen, B. Wang, S. Huang, M Song. Sci. of The Tot. Env. 735, 139456 (2020)

7. Kunming Li, Liting Fang, Lerong He. Enrgy. Pol. 129:386-396 (2019)

8. A. Ville, F. Lavigne, C. Virmoux, D. Brunstein, E. De Bélizal, S.B. Wibowo, and D.S. Hadmoko, GRPE, 21,3:235-250 (2015)

9. S.B. Wibowo, I.W. Nurani, Improving geoinformation technology by incorporating local participation, in Proceedings of the Sixth Geoinformation Science Symposium, GSS, 26-27 August 2019. Yogyakarta, Indonesia (2019)

10. Dinas Lingkungan Hidup, Buku II Informasi Kinerja Pengelolaan Lingkungan Hidup Daerah (IKPLHD) Kabupaten Bandung Tahun 2018, Dinas Lingkungan Hidup Kabupaten Bandung, Bandung (2018)

11. D. Wulandari, S. Utomo, B. Narmaditya, Int. J. of Enrgy Econ. and Policy, 7:36-41 (2017)

12. Prabowo, S. Pranoto, S. Budiastuti, J. Bioeksperimen. 5,1:21-33 (2019)

13. Peraturan Presiden Nomor 61 tahun 2011 tentang Rencana Aksi Nasional- Gas Rumah Kaca (RANGRK) (2011)

14. J.W. Creswell, Research Design Qualitative, Quantitative and Mixed Methods Approaches, Third Edition, Sage Publications, California (2009)

15. IPCC, IPCC Guidelines for National Greenhouse Gas Inventories. Institute for Global Environmental Strategies (IGES) on behalf of the IPCC, Hayama (2006)

16. Q. Nugrahayu, N. Nurjannah, L. Hakim, J. Sains dan Tekno. Ling., 9, 1. (2017)

17. A. Kiswadayani, L. Susanawati, L, R. Wirosoedarmo, J. SDA dan Ling., 2, 3. (2015)

18. N. Prayati, N. Kartika, E-Jurnal Eko, 7, 6 (2018)

19. R. Pratama, M. Ihsan, J. Tek. Ling. 18, 1 (2017)

20. A. Suryani, Aspirasi, 5, 1 (2014)

21. Peraturan Menteri Negara Lingkungan Hidup Nomor 13 tahun 2012 tentang Pedoman Pelaksanaan Reduce, Reuse, Recycle melalui Bank Sampah

22. Indartik, E.Y. Suryandari, D. Djaenudin, M.A. Pribadi, J. Pen. Sosek Kehutann. 15, 3 (2018)

23. N. Indrianti, Procedia-Soc. and Behav. Sci. 224, 158-166 (2016)

24. W.S. Wardhana, H Tolle, A.P. Kharisma, J. Peng. Tek Inf dan Il Komp., 3, 6548-6555 (2019) 